\title{
Epigenetic Control of Circadian Clock Operation during Development
}

\author{
Chengwei Li, Changxia Gong, Shuang Yu, Jianguo Wu, and Xiaodong Li \\ National Key Laboratory of Virology, College of Life Sciences, Wuhan University, Luojia Hill, Wuchang District, Hubei, \\ Wuhan 430072, China \\ Correspondence should be addressed to Xiaodong Li, xiaodli@whu.edu.cn
}

Received 30 August 2011; Revised 22 December 2011; Accepted 13 January 2012

Academic Editor: Elfride De Baere

Copyright (C) 2012 Chengwei Li et al. This is an open access article distributed under the Creative Commons Attribution License, which permits unrestricted use, distribution, and reproduction in any medium, provided the original work is properly cited.

The molecular players of circadian clock oscillation have been identified and extensively characterized. The epigenetic mechanisms behind the circadian gene expression control has also been recently studied, although there are still details to be illucidated. In this review, we briefly summarize the current understanding of the mammalian clock. We also provide evidence for the lack of circadian oscillation in particular cell types. As the circadian clock has intimate interaction with the various cellular functions in different type of cells, it must have plasticity and specicity in its operation within different epigenetic environments. The lack of circadian oscillation in certain cells provide an unique opportunity to study the required epigenetic environment in the cell that permit circadian oscillation and to idenfify key influencing factors for proper clock function. How epigenetic mechansims, including DNA methylaiton and chromatin modifications, participate in control of clock oscillation still awaits future studies at the genomic scale.

\section{Introduction}

Mammals have overt circadian rhythms in their physiology and behavior, orchestrated by the suprachiasmatic nucleus of the anterior hypothalamus $[1,2]$. The endogenous circadian clock enables organisms to anticipate the regular daily changes in the environment and temporally organize their life activities $[3,4]$. Fundamentally, circadian timing functions exist at the cellular level not only for suprachiasmatic neurons, but also for cells of various peripheral tissues [5-9].

\section{A Brief Overview of Clockwork Mechanisms}

The past two decades witnessed the rapid pace in gaining indepth understanding of mammalian clockwork operation. Circadian oscillations are generated at the molecular level by a set of clock genes [10-12]. The mapping and cloning of the Clock ${ }^{\Delta 19}$ mutation through ENU mutagenesis and positional cloning set the stage for elucidation of mammalian clockwork mechanisms [13-15]. BMAL1 was soon identified to be the dimerization partner of CLOCK to drive clock gene expression [16, 17]. Mouse Per genes were also identified and found to be driven by the CLOCK/BMAL1 dimer [1820]. CRY1 and CRY2 were later found to have essential roles in the integrity of the circadian clock through inhibiting CLOCK/BMAL1-mediated transcription activation [21, 22]. Thus CLOCK and BMAL1 form the positive limb, while CRY and PER proteins form the negative limb of the transcriptional feedback loop [23]. Later on, more details were elucidated and revisions were made for the clockwork model, including the antagonistic regulations of Bmall transcription by REV-ERB $\alpha$ and RORa [24-26], additional clock genes such as Npas2 and Bmal2, and posttranscriptional regulation of clock genes' transcripts [27-29]. CRYs interact with the CLOCK/BMAL1 dimer through interactions with PER proteins [30]. Clock proteins are subject to posttranslational modifications that affect their stability, cellular localization, and transcriptional activities [31,32]. Several kinases were shown to phosphorylate PER proteins [3338]. Defects in PER phosphorylation have been linked with changes in circadian period $[33,39,40]$, although the mechanisms responsible for the observed phenotypes 
are still not unambiguous [34, 41-44]. Nevertheless, posttranslational modifications, in controlling subcellular localization, interaction, and stability of clock proteins, are essential for the delay between transcriptional activation and feedback inhibition that is critical to robust circadian oscillation [30, 45-48]. The clockwork components can also be influenced by multiple cellular signaling pathways to adjust the phases of the running clock [49-58]. Operation of the clockwork can impose temporal expression on the transcriptome with gene expression levels peaking at defined times over the day $[59,60]$. The daily interactions between transcriptional activators and inhibitors of the clockwork and their corresponding cis regulatory elements on target genes [12] can achieve sophisticated phase control over gene expression rhythms $[48,61]$.

\section{Epigenetics: Circadian Rhythms of Gene Expression}

Eukaryotic genomic DNA is packaged around histone proteins into repeating nucleosome units, which further form higher-order chromatin structures [62]. Histones are subject to various modifications and chromatin is remodeled according to cellular needs [63-66]. The so-called "histonecode" $[67,68]$, or more appropriately "histone language" [69, 70], of various histone modifications and their combinations influences gene transcription activities. CpG methylations within DNA sequences affect histone modifications and nucleosomal organization to impact gene transcription [71, 72]. Current evidence indicates that DNA methylation and histone modifications are intimately linked [73-75].

DNA methylation, histone modifications, and chromatin remodeling are the cornerstones of epigenetics. Epigenetics was originally defined as "the study of mitotically and/or meiotically heritable changes in gene function that cannot be explained by changes in DNA sequence" [76]. A more generalized definition was recently proposed "to avoid the constraints imposed by stringently requiring heritability": epigenetic events are "the structural adaptation of chromosomal regions so as to register, signal or perpetuate altered activity states" [76]. According to this definition, the daily changes of gene expression driven by the cellular clock and the clock's response to external input all fall into the realm of epigenetics [77]. The core clock genes such as CLOCK/BMAL1 and PERs/CRYs are classified as the positive and negative regulators of the clockwork, respectively. CLOCK possesses intrinsic HAT activity [78]. Biochemical characterization of protein complexes containing clock proteins has found additional proteins involved in histone modifications [7983]. Changes in histone modifications are also associated with rhythmic expression of clock genes [82, 84]. In the thoroughly studied case of circadian $D b p$ expression, daily changes in histone modifications and nucleosome packing accompanied rhythmic CLOCK/BMAL1 bindings to E boxes within the Dbp locus [85-87]. Thus it appears that the circadian clock exerts transcriptional regulation through mechanisms involving histone modifications, although there is still much to be learned, due to the complexity of transcriptional control [88-90]. Intimate interactions also exist between the clockwork and the cellular metabolism [91-94]. Metabolism coupling to the clockwork is also through mediators such as SIRT1, PARP-1, and REV-ERB $\alpha$-NCOR1-HDAC3, that act directly or indirectly through chromatin modification mechanisms [95-99]. CLOCK/BMAL1's binding to the Ebox elements and presumably their transcriptional activities are regulated by their post-translational modifications rather than directly by their abundance $[32,45,87,96]$. CRYs and PERs seem to destabilize/disrupt CLOCK/BMAL1 binding to E-boxes [87], with post-translational modifications in PER2 affect its inhibitory effect on CLOCK/BMAL1 transcriptional activation $[30,95]$. It should be noted that different Ebox elements within their genomic context seem to differ in their affinities of CLOCK/BMAL1 binding, and direct CRY1 recruitment by CLOCK/BMAL1 to the E-box element within $D b p$ promoter (but not intragenic E-boxes of $D b p$ ) has been demonstrated [100]. While circadian changes in DNA methylation in the promoters of clock genes or clockcontrolled genes have not been reported to our knowledge, epigenetic inactivation of clock genes due to promoter DNA methylation has been reported in various cancer cells [101]. Specifically in the nervous system, methyl-CpG-binding protein 2 (MeCP2) could be phosphorylated due to neuronal activity and phosphorylation relieves MeCP2's binding to methylated DNA and the inhibition of target gene's of transcription [102]. Light signaling to the central clock in the SCN has been shown to cause MeCP2 phosphorylation [103], in addition to inducing histone modifications that parallel the induction of immediate early genes [104].

\section{Are Cellular Clocks Ubiquitous? The Case during Development}

Most adult tissues have endogenous clocks. Peripheral tissues are typically derived from distinct lineages during development and are specialized for distinct functions. The clockwork must intersect with the unique cellular environments in different types of cells [105]. There are a few exceptions to the omnipresence of the circadian clocks in adult tissues. In the nervous system, few brain regions other than the SCN were shown to have endogenous circadian oscillations [106]. Cells during spermatogenesis have been shown to have clock genes' expression patterns not consistent with clock oscillation [107-109]. Similar observations were also made in immature $\mathrm{T}$ cells in the thymus [110]. It is a challenge to characterize the cellular environments that are permissive to circadian oscillation in specific types of cells.

The oscillation status of the cellular clock during development is largely unclear [111]. Downregulation of clock genes' transcripts (possibly of maternal origin) was seen after fertilization in the zygote [112], without apparent zygotic activation of endogenous expression [113]. In mouse embryonic stem cells, imaging studies at the single-cell level also failed to detect circadian oscillations (which appear after differentiation of the ES cells) $[114,115]$. Although clock genes' transcripts could be detected in the conceptus and various mouse fetal tissues [111], circadian rhythmicity 
in their abundance was rarely detected [116]. Adult-like rhythmic patterns in their expressions were detected only during postnatal development [117]. Paracrine mechanism has been postulated to account for intrinsic synchrony at the tissue level in adult mice [118]. Such mechanisms, while their existence still debatable $[119,120]$, apparently did not play a role in fetal tissues, which lacked overt circadian rhythmicities at the tissue level [116]. Peripheral clocks of adult tissues are influenced by signals from the central clock $[8,120,121]$. The central clock exerts control over peripheral clocks through neural [122], hormonal [123], systemic cues as a result of feeding control [123-125], and daily body temperature changes $[58,126]$. Different tissues may respond differentially to those cues, and those cues may also have complex actions toward the same tissue under different feeding conditions $[119,127,128]$. Fetal tissues most likely were under the influence of rhythmic maternal cues. It is peculiar that clock genes, while obviously expressed, did not seem to form the transcriptional/translation feedback loop in the fetal liver $[116,117]$. It is possible that fetal clocks were oscillating at the cellular level but were not synchronized/entrained by maternal rhythms. However, it is also well known that fetal tissues such as the liver clearly differed in differentiation state and metabolic activities from the adult liver [129]. Those functional differences are likely accompanied with transcriptome and epigenomic differences between fetal and adult livers, as cellular epigenetic profiles change during development $[72,130,131]$. Thus fetal mouse liver might possess a unique epigenomic environment that was not permissive to cellular circadian oscillation [105]. Furthermore, the cellular redox ratio $([\mathrm{NAD}+] /[\mathrm{NADH}])$ is known to be very low in the fetal rat liver [132], a situation potentially leading to compromised cellular oscillation due to limited SIRT1 function [95]. It should be noted that in other mammals, such as the primates, the cellular clocks might oscillate in the fetal liver [133].

Development of the circadian timing function is independent of maternal rhythms and resilient to perturbations $[134,135]$. However, the clock during ontogeny was suggested to be entrained by maternal rhythms [136139]. The central clock in the SCN has been shown to oscillate soon after neurogenesis before birth [140]. It could also be affected by exogenous agents such as D1 receptor agonist and melatonin [141, 142]. However, the entrainment mechanisms are largely unknown. For example, D1 receptor agonist is known to induce $c$-fos in the fetal SCN, but it has not been documented whether prenatal D1 agonist treatment led to induction of core clock genes [143]. Melatonin, on the other hand, did not seem to act by induction of immediateearly genes in the fetal SCN [144]. Molecular oscillations of clock gene expression in the suprachiasmatic nucleus were typically weak before birth $[145,146]$. The perinatal period is accompanied by changes in hormonal milieu that could trigger epigenetic changes in certain genes [147-149]. We recently found perinatal changes in methylation status of the mPer 1 promoter in the suprachiasmatic nucleus [150]. The significance of this change to clock operation and phase resetting remained to be fully elucidated.

\section{Perspective}

The circadian clock is an essential component of cellular functions in various adult tissues. In fetal tissues and ES cells, such oscillation might not operate. However, previous studies often analyzed daily changes in transcripts' abundance to probe the oscillation status of the clock. Few studies addressed the relative abundance of those transcripts' and their protein products' stoichiometry and posttranslational modifications. The circadian clock is resistant to large fluctuations in overall transcription rates [151]. The clock can also tolerate changes in some components' expression patterns $[30,152-154]$. However, rigorous requirements are imposed on the expression rhythms of some clock genes [30, 48, 155]. Future studies should investigate the subcellular distribution and chromatin association of clock genes' products in fetal tissues and ES cells to get a more comprehensive picture of the operation status of the clockwork therein. The epigenomic environment of the fetal tissues and ES cells should also be investigated to address their unpermissiveness to clock operation.

\section{Acknowledgments}

This work was supported by National Mega Project on Major Drug Development (2011ZX09401-302-1 and 2009ZX09301-014-1) and by the China Ministry of Education Grant 20070486102.

\section{References}

[1] R. Y. Moore and V. B. Eichler, "Loss of a circadian adrenal corticosterone rhythm following suprachiasmatic lesions in the rat," Brain Research, vol. 42, no. 1, pp. 201-206, 1972.

[2] F. K. Stephan and I. Zucker, "Circadian rhythms in drinking behavior and locomotor activity of rats are eliminated by hypothalamic lesions," Proceedings of the National Academy of Sciences of the United States of America, vol. 69, no. 6, pp. 1583-1586, 1972.

[3] C. S. Pittendrigh, "Temporal organization: reflections of a Darwinian clock-watcher," Annual Review of Physiology, vol. 55, pp. 17-54, 1993.

[4] S. Daan, "Colin Pittendrigh, Jurgen Aschoff, and the natural entrainment of circadian systems," Journal of Biological Rhythms, vol. 15, no. 3, pp. 195-207, 2000.

[5] D. K. Welsh, D. E. Logothetis, M. Meister, and S. M. Reppert, "Individual neurons dissociated from rat suprachiasmatic nucleus express independently phased circadian firing rhythms," Neuron, vol. 14, no. 4, pp. 697-706, 1995.

[6] D. K. Welsh, S. H. Yoo, A. C. Liu, J. S. Takahashi, and S. A. Kay, "Bioluminescence imaging of individual fibroblasts reveals persistent, independently phased circadian rhythms of clock gene expression," Current Biology, vol. 14, no. 24, pp. 2289-2295, 2004.

[7] U. Schibler, J. Ripperger, and S. A. Brown, "Peripheral circadian oscillators in mammals: time and food," Journal of Biological Rhythms, vol. 18, no. 3, pp. 250-260, 2003.

[8] M. H. Hastings, A. B. Reddy, and E. S. Maywood, "A clockwork web: circadian timing in brain and periphery, in health and disease," Nature Reviews Neuroscience, vol. 4, no. 8, pp. 649-661, 2003. 
[9] C. Dibner, U. Schibler, and U. Albrecht, "The mammalian circadian timing system: organization and coordination of central and peripheral clocks," Annual Review of Physiology, vol. 72, pp. 517-549, 2009.

[10] S. M. Reppert and D. R. Weaver, "Coordination of circadian timing in mammals," Nature, vol. 418, no. 6901, pp. 935-941, 2002.

[11] J. S. Takahashi, H. K. Hong, C. H. Ko, and E. L. McDearmon, "The genetics of mammalian circadian order and disorder: implications for physiology and disease," Nature Reviews Genetics, vol. 9, no. 10, pp. 764-775, 2008.

[12] H. Ukai and H. R. Ueda, "Systems biology of mammalian circadian clocks," Annual Review of Physiology, vol. 72, pp. 579-603, 2010.

[13] M. H. Vitaterna, D. P. King, A. M. Chang et al., "Mutagenesis and mapping of a mouse gene, clock, essential for circadian behavior," Science, vol. 264, no. 5159, pp. 719-725, 1994.

[14] M. P. Antoch, E. J. Song, A. M. Chang et al., "Functional identification of the mouse circadian Clock gene by transgenic BAC rescue," Cell, vol. 89, no. 4, pp. 655-667, 1997.

[15] D. P. King, Y. Zhao, A. M. Sangoram et al., "Positional cloning of the mouse circadian Clock gene," Cell, vol. 89, no. 4, pp. 641-653, 1997.

[16] J. B. Hogenesch, Y. Z. Gu, S. Jain, and C. A. Bradfield, "The basic-helix-loop-helix-PAS orphan MOP3 forms transcriptionally active complexes with circadian and hypoxia factors," Proceedings of the National Academy of Sciences of the United States of America, vol. 95, no. 10, pp. 5474-5479, 1998.

[17] N. Gekakis, D. Staknis, H. B. Nguyen et al., "Role of the CLOCK protein in the mammalian circadian mechanism," Science, vol. 280, no. 5369, pp. 1564-1569, 1998.

[18] Z. S. Sun, U. Albrecht, O. Zhuchenko, J. Bailey, G. Eichele, and C. C. Lee, "RIGUI, a putative mammalian ortholog of the Drosophila period gene," Cell, vol. 90, no. 6, pp. 10031011, 1997.

[19] H. Tei, H. Okamura, Y. Shigeyoshi et al., "Circadian oscillation of a mammalian homologue of the Drosophila period gene," Nature, vol. 389, no. 6650, pp. 512-516, 1997.

[20] M. J. Zylka, L. P. Shearman, D. R. Weaver, and S. M. Reppert, "Three period homologs in mammals: differential light responses in the suprachiasmatic circadian clock and oscillating transcripts outside of brain," Neuron, vol. 20, no. 6, pp. 1103-1110, 1998.

[21] G. T. J. Van Der Horst, M. Muijtjens, K. Kobayashi et al., "Mammalian Cryl and Cry2 are essential for maintenance of circadian rhythms," Nature, vol. 398, no. 6728, pp. 627-630, 1999.

[22] K. Kume, M. J. Zylka, S. Sriram et al., "mCRY1 and mCRY2 are essential components of the negative limb of the circadian clock feedback loop," Cell, vol. 98, no. 2, pp. 193-205, 1999.

[23] L. P. Shearman, S. Sriram, D. R. Weaver et al., "Interacting molecular loops in the mammalian circadian clock," Science, vol. 288, no. 5468, pp. 1013-1019, 2000.

[24] N. Preitner, F. Damiola, Luis-Lopez-Molina et al., "The orphan nuclear receptor REV-ERB $\alpha$ controls circadian transcription within the positive limb of the mammalian circadian oscillator," Cell, vol. 110, no. 2, pp. 251-260, 2002.

[25] T. K. Sato, S. Panda, L. J. Miraglia et al., "A functional genomics strategy reveals rora as a component of the mammalian circadian clock," Neuron, vol. 43, no. 4, pp. 527-537, 2004.

[26] M. Akashi and T. Takumi, "The orphan nuclear receptor $\mathrm{ROR} \alpha$ regulates circadian transcription of the mammalian core-clock Bmal1," Nature Structural and Molecular Biology, vol. 12, no. 5, pp. 441-448, 2005.

[27] M. Reick, J. A. Garcia, C. Dudley, and S. L. McKnight, "NPAS2: an analog of clock operative in the mammalian forebrain," Science, vol. 293, no. 5529, pp. 506-509, 2001.

[28] S. Shi, A. Hida, O. P. McGuinness, D. H. Wasserman, S. Yamazaki, and C. H. Johnson, "Circadian clock gene Bmal1 is not essential; functional replacement with its paralog, Bmal2," Current Biology, vol. 20, no. 4, pp. 316-321, 2010.

[29] K. C. Woo, T. D. Kim, K. H. Lee et al., "Mouse period 2 mRNA circadian oscillation is modulated by PTB-mediated rhythmic mRNA degradation," Nucleic Acids Research, vol. 37, no. 1, pp. 26-37, 2009.

[30] R. Chen, A. Schirmer, Y. Lee et al., "Rhythmic PER abundance defines a critical nodal point for negative feedback within the circadian clock mechanism," Molecular Cell, vol. 36, no. 3, pp. 417-430, 2009.

[31] M. Gallego and D. M. Virshup, "Post-translational modifications regulate the ticking of the circadian clock," Nature Reviews Molecular Cell Biology, vol. 8, no. 2, pp. 139-148, 2007.

[32] C. Lee, J. P. Etchegaray, F. R. A. Cagampang, A. S. I. Loudon, and S. M. Reppert, "Posttranslational mechanisms regulate the mammalian circadian clock," Cell, vol. 107, no. 7, pp. 855-867, 2001.

[33] M. R. Ralph and M. Menaker, "A mutation of the circadian system in golden hamsters," Science, vol. 241, no. 4870, pp. 1225-1227, 1988.

[34] P. L. Lowrey, K. Shimomura, M. P. Antoch et al., "Positional syntenic cloning and functional characterization of the mammalian circadian mutation tau," Science, vol. 288, no. 5465, pp. 483-491, 2000.

[35] J. P. Etchegaray, K. K. Machida, E. Noton et al., "Casein kinase 1 delta regulates the pace of the mammalian circadian clock," Molecular and Cellular Biology, vol. 29, no. 14, pp. 3853-3866, 2009.

[36] Y. Isojima, M. Nakajima, H. Ukai et al., "CKI $\varepsilon / \delta$-dependent phosphorylation is a temperature-insensitive, perioddetermining process in the mammalian circadian clock," Proceedings of the National Academy of Sciences of the United States of America, vol. 106, no. 37, pp. 15744-15749, 2009.

[37] H. Lee, R. Chen, Y. Lee, S. Yoo, and C. Lee, "Essential roles of CKI $\delta$ and CKI $\varepsilon$ in the mammalian circadian clock," Proceedings of the National Academy of Sciences of the United States of America, vol. 106, no. 50, pp. 21359-21364, 2009.

[38] B. Maier, S. Wendt, J. T. Vanselow et al., "A large-scale functional RNAi screen reveals a role for CK2 in the mammalian circadian clock," Genes and Development, vol. 23, no. 6, pp. 708-718, 2009.

[39] K. L. Toh, C. R. Jones, Y. He et al., "An hPer2 phosphorylation site mutation in familial advanced sleep phase syndrome," Science, vol. 291, no. 5506, pp. 1040-1043, 2001.

[40] Y. Xu, Q. S. Padiath, R. E. Shapiro et al., "Functional consequences of a CKI $\delta$ mutation causing familial advanced sleep phase syndrome," Nature, vol. 434, no. 7033, pp. 640-644, 2005.

[41] Y. Xu, K. L. Toh, C. R. Jones, J. Y. Shin, Y. H. Fu, and L. J. Ptáček, "Modeling of a human circadian mutation yields insights into clock regulation by PER2," Cell, vol. 128, no. 1, pp. 59-70, 2007.

[42] E. Mignot and J. S. Takahashi, "A circadian sleep disorder reveals a complex clock," Cell, vol. 128, no. 1, pp. 22-23, 2007.

[43] K. Vanselow, J. T. Vanselow, P. O. Westermark et al., "Differential effects of PER2 phosphorylation: molecular basis 
for the human familial advanced sleep phase syndrome (FASPS)," Genes and Development, vol. 20, no. 19, pp. 2660 2672, 2006.

[44] M. Gallego, E. J. Eide, M. F. Woolf, D. M. Virshup, and D. B. Forger, "An opposite role for tau in circadian rhythms revealed by mathematical modeling," Proceedings of the $\mathrm{Na}$ tional Academy of Sciences of the United States of America, vol. 103, no. 28, pp. 10618-10623, 2006.

[45] I. Kwon, J. Lee, S. H. Chang et al., "BMAL1 shuttling controls transactivation and degradation of the CLOCK/BMAL1 heterodimer," Molecular and Cellular Biology, vol. 26, no. 19, pp. 7318-7330, 2006.

[46] S. M. Siepka, S. H. Yoo, J. Park et al., "Circadian mutant overtime reveals F-box protein FBXL3 regulation of cryptochrome and period gene expression," Cell, vol. 129, no. 5, pp. 1011-1023, 2007.

[47] K. Yagita, F. Tamanini, M. Yasuda, J. H. J. Hoeijmakers, G. T. J. Van der Horst, and H. Okamura, "Nucleocytoplasmic shuttling and mCRY-dependent inhibition of ubiquitylation of the mPER2 clock protein," EMBO Journal, vol. 21, no. 6, pp. 1301-1314, 2002.

[48] M. Ukai-Tadenuma, R. G. Yamada, H. Xu, J. A. Ripperger, A. C. Liu, and H. R. Ueda, "Delay in feedback repression by cryptochrome 1 Is required for circadian clock function," Cell, vol. 144, no. 2, pp. 268-281, 2011.

[49] D. D. Ginty, J. M. Kornhauser, M. A. Thompson et al., "Regulation of CREB phosphorylation in the suprachiasmatic nucleus by light and a circadian clock," Science, vol. 260, no. 5105, pp. 238-241, 1993.

[50] D. Gau, T. Lemberger, C. Von Gall et al., "Phosphorylation of CREB Ser142 regulates light-induced phase shifts of the circadian clock," Neuron, vol. 34, no. 2, pp. 245-253, 2002.

[51] Z. Travnickova-Bendova, N. Cermakian, S. M. Reppert, and P. Sassone-Corsi, "Bimodal regulation of mPeriod promoters by CREB-dependent signaling and CLOCK/BMAL1 activity," Proceedings of the National Academy of Sciences of the United States of America, vol. 99, no. 11, pp. 7728-7733, 2002.

[52] A. Balsalobre, L. Marcacci, and U. Schibler, "Multiple signaling pathways elicit circadian gene expression in cultured Rat1 fibroblasts," Current Biology, vol. 10, no. 20, pp. 1291-1294, 2000.

[53] B. Lee, A. Almad, G. Q. Butcher, and K. Obrietan, "Protein kinase $\mathrm{C}$ modulates the phase-delaying effects of light in the mammalian circadian clock," European Journal of Neuroscience, vol. 26, no. 2, pp. 451-462, 2007.

[54] H. S. Shim, H. Kim, J. Lee et al., "Rapid activation of CLOCK by $\mathrm{Ca} 2^{+}$-dependent protein kinase $\mathrm{C}$ mediates resetting of the mammalian circadian clock," EMBO Reports, vol. 8, no. 4, pp. 366-371, 2007.

[55] L. Yin, J. Wang, P. S. Klein, and M. A. Lazar, "Nuclear receptor Rev-erb $\alpha$ is a critical lithium-sensitive component of the circadian clock," Science, vol. 311, no. 5763, pp. 1002-1005, 2006.

[56] K. A. Lamia, U. M. Sachdeva, L. Di Tacchio et al., "AMPK regulates the circadian clock by cryptochrome phosphorylation and degradation," Science, vol. 326, no. 5951, pp. 437-440, 2009.

[57] K. Sanada, T. Okano, and Y. Fukada, "Mitogen-activated protein kinase phosphorylates and negatively regulates basic helix-loop-helix-PAS transcription factor BMAL1," Journal of Biological Chemistry, vol. 277, no. 1, pp. 267-271, 2002.

[58] H. Reinke, C. Saini, F. Fleury-Olela, C. Dibner, I. J. Benjamin, and U. Schibler, "Differential display of DNA-binding proteins reveals heat-shock factor 1 as a circadian transcription factor," Genes and Development, vol. 22, no. 3, pp. 331-345, 2008.

[59] S. Panda, M. P. Antoch, B. H. Miller et al., "Coordinated transcription of key pathways in the mouse by the circadian clock," Cell, vol. 109, no. 3, pp. 307-320, 2002.

[60] K. F. Storch, O. Lipan, I. Leykin et al., "Extensive and divergent circadian gene expression in liver and heart," Nature, vol. 417, no. 6884, pp. 78-83, 2002.

[61] M. Stratmann, F. Stadler, F. Tamanini, G. T. J. Van Der Horst, and J. A. Ripperger, "Flexible phase adjustment of circadian albumin $\mathrm{D}$ site-binding protein (Dbp) gene expression by CRYPTOCHROME1," Genes and Development, vol. 24, no. 12, pp. 1317-1328, 2010.

[62] R. D. Kornberg and Y. Lorch, "Twenty-five years of the nucleosome, fundamental particle of the eukaryote chromosome," Cell, vol. 98, no. 3, pp. 285-294, 1999.

[63] T. Kouzarides, "Chromatin modifications and their function,” Cell, vol. 128, no. 4, pp. 693-705, 2007.

[64] C. R. Clapier and B. R. Cairns, "The biology of chromatin remodeling complexes," Annual Review of Biochemistry, vol. 78, pp. 273-304, 2009.

[65] A. J. Ruthenburg, H. Li, D. J. Patel, and C. David Allis, "Multivalent engagement of chromatin modifications by linked binding modules," Nature Reviews Molecular Cell Biology, vol. 8, no. 12, pp. 983-994, 2007.

[66] S. R. Bhaumik, E. Smith, and A. Shilatifard, "Covalent modifications of histones during development and disease pathogenesis," Nature Structural and Molecular Biology, vol. 14, no. 11, pp. 1008-1016, 2007.

[67] B. D. Strahl and C. D. Allis, "The language of covalent histone modifications," Nature, vol. 403, no. 6765, pp. 41-45, 2000.

[68] T. Jenuwein and C. D. Allis, "Translating the histone code," Science, vol. 293, no. 5532, pp. 1074-1080, 2001.

[69] R. J. Sims and D. Reinberg, "Is there a code embedded in proteins that is based on post-translational modifications?" Nature Reviews Molecular Cell Biology, vol. 9, no. 10, pp. 815820, 2008.

[70] J. S. Lee, E. Smith, and A. Shilatifard, "The language of histone crosstalk," Cell, vol. 142, no. 5, pp. 682-685, 2010.

[71] M. J. Fazzari and J. M. Greally, "Epigenomics: beyond CpG islands," Nature Reviews Genetics, vol. 5, no. 6, pp. 446-455, 2004.

[72] E. Li, "Chromatin modification and epigenetic reprogramming in mammalian development," Nature Reviews Genetics, vol. 3, no. 9, pp. 662-673, 2002.

[73] J. L. Hu, B. O. Zhou, R. R. Zhang, K. L. Zhang, J. Q. Zhou, and G. L. Xu, "The N-terminus of histone $\mathrm{H} 3$ is required for de novo DNA methylation in chromatin," Proceedings of the National Academy of Sciences of the United States of America, vol. 106, no. 52, pp. 22187-22192, 2009.

[74] J. P. Thomson, P. J. Skene, J. Selfridge et al., "CpG islands influence chromatin structure via the CpG-binding protein Cfp1," Nature, vol. 464, no. 7291, pp. 1082-1086, 2010.

[75] H. Cedar and Y. Bergman, "Linking DNA methylation and histone modification: patterns and paradigms," Nature Reviews Genetics, vol. 10, no. 5, pp. 295-304, 2009.

[76] A. Bird, "Perceptions of epigenetics," Nature, vol. 447, no. 7143, pp. 396-398, 2007.

[77] R. Jaenisch and A. Bird, "Epigenetic regulation of gene expression: how the genome integrates intrinsic and environmental signals," Nature Genetics, vol. 33, pp. 245-254, 2003.

[78] M. Doi, J. Hirayama, and P. Sassone-Corsi, "Circadian regulator CLOCK is a histone acetyltransferase," Cell, vol. 125, no. 3, pp. 497-508, 2006. 
[79] S. A. Brown, J. Ripperger, S. Kadener et al., "Cell biology: PERIOD1-associated proteins modulate the negative limb of the mammalian circadian oscillator," Science, vol. 308, no. 5722, pp. 693-696, 2005.

[80] H. A. Duong, M. S. Robles, D. Knutti, and C. J. Weitz, "A molecular mechanism for circadian clock negative feedback," Science, vol. 332, no. 6036, pp. 1436-1439, 2011.

[81] S. Katada and P. Sassone-Corsi, "The histone methyltransferase MLL1 permits the oscillation of circadian gene expression," Nature Structural and Molecular Biology, vol. 17, no. 12, pp. 1414-1421, 2010.

[82] Y. Naruse, K. Oh-Hashi, N. Iijima, M. Naruse, H. Yoshioka, and M. Tanaka, "Circadian and light-induced transcription of clock gene Per1 depends on histone acetylation and deacetylation," Molecular and Cellular Biology, vol. 24, no. 14, pp. 6278-6287, 2004.

[83] L. DiTacchio, H. D. Le, C. Vollmers et al., "Histone lysine demethylase JARID1a activates CLOCK-BMAL1 and influences the circadian clock," Science, vol. 333, no. 6051, pp. 1881-1885, 2011.

[84] J. P. Etchegaray, C. Lee, P. A. Wade, and S. M. Reppert, "Rhythmic histone acetylation underlies transcription in the mammalian circadian clock," Nature, vol. 421, no. 6919, pp. 177-182, 2003.

[85] C. R. Mueller, P. Maire, and U. Schibler, "DBP, a liver-enriched transcriptional activator, is expressed late in ontogeny and its tissue specificity is determined posttranscriptionally," Cell, vol. 61, no. 2, pp. 279-291, 1990.

[86] J. A. Ripperger, L. P. Shearman, S. M. Reppert, and U. Schibler, "CLOCK, an essential pacemaker component, controls expression of the circadian transcription factor DBP," Genes and Development, vol. 14, no. 6, pp. 679-689, 2000.

[87] J. A. Ripperger and U. Schibler, "Rhythmic CLOCK-BMAL1 binding to multiple E-box motifs drives circadian Dbp transcription and chromatin transitions," Nature Genetics, vol. 38, no. 3, pp. 369-374, 2006.

[88] N. J. Fuda, M. B. Ardehali, and J. T. Lis, "Defining mechanisms that regulate RNA polymerase II transcription in vivo," Nature, vol. 461, no. 7261, pp. 186-192, 2009.

[89] D. M. Suter, N. Molina, D. Gatfield, K. Schneider, U. Schibler, and F. Naef, "Mammalian genes are transcribed with widely different bursting kinetics," Science, vol. 332, no. 6028, pp. 472-474, 2011.

[90] D. M. Suter, N. Molina, F. Naef, and U. Schibler, "Origins and consequences of transcriptional discontinuity," Current Opinion in Cell Biology, vol. 23, no. 6, pp. 657-662, 2011.

[91] J. Bass and J. S. Takahashi, "Circadian integration of metabolism and energetics," Science, vol. 330, no. 6009, pp. 13491354, 2010.

[92] G. Asher and U. Schibler, "Crosstalk between components of circadian and metabolic cycles in mammals," Cell Metabolism, vol. 13, no. 2, pp. 125-137, 2011.

[93] M. M. Bellet and P. Sassone-Corsi, "Mammalian circadian clock and metabolism - the epigenetic link," Journal of Cell Science, vol. 123, no. 22, pp. 3837-3848, 2010.

[94] K. Eckel-Mahan and P. Sassone-Corsi, "Metabolism control by the circadian clock and vice versa," Nature Structural and Molecular Biology, vol. 16, no. 5, pp. 462-467, 2009.

[95] G. Asher, D. Gatfield, M. Stratmann et al., "SIRT1 regulates circadian clock gene expression through PER2 deacetylation," Cell, vol. 134, no. 2, pp. 317-328, 2008.

[96] G. Asher, H. Reinke, M. Altmeyer, M. Gutierrez-Arcelus, M. O. Hottiger, and U. Schibler, "Poly(ADP-Ribose) polymerase
1 participates in the phase entrainment of circadian clocks to feeding," Cell, vol. 142, no. 6, pp. 943-953, 2010.

[97] Y. Nakahata, M. Kaluzova, B. Grimaldi et al., "The NAD ${ }^{+}$dependent deacetylase SIRT1 modulates CLOCK-mediated chromatin remodeling and circadian control," Cell, vol. 134, no. 2, pp. 329-340, 2008.

[98] Y. Nakahata, S. Sahar, G. Astarita, M. Kaluzova, and P. Sassone-Corsi, "Circadian control of the $\mathrm{NAD}^{+}$salvage pathway by CLOCK-SIRT1,” Science, vol. 324, no. 5927, pp. 654-657, 2009.

[99] K. M. Ramsey, J. Yoshino, C. S. Brace et al., "Circadian clock feedback cycle through NAMPT-Mediated NAD" biosynthesis," Science, vol. 324, no. 5927, pp. 651-654, 2009.

[100] I. Schmutz, J. A. Ripperger, S. Baeriswyl-Aebischer, and U. Albrecht, "The mammalian clock component PERIOD2 coordinates circadian output by interaction with nuclear receptors," Genes and Development, vol. 24, no. 4, pp. 345-357, 2010.

[101] J. A. Ripperger and M. Merrow, "Perfect timing: epigenetic regulation of the circadian clock," FEBS Letters, vol. 585, no. 10, pp. 1406-1411, 2011.

[102] W. G. Chen, Q. Chang, Y. Lin et al., "Derepression of BDNF transcription involves calcium-dependent phosphorylation of MeCP2," Science, vol. 302, no. 5646, pp. 885-889, 2003.

[103] Z. Zhou, E. J. Hong, S. Cohen et al., "Brain-specific phosphorylation of $\mathrm{MeCP} 2$ regulates activity-dependent Bdnf transcription, dendritic growth, and spine maturation," Neuron, vol. 52, no. 2, pp. 255-269, 2006.

[104] C. Crosio, N. Cermakian, C. D. Allis, and P. Sassone-Corsi, "Light induces chromatin modification in cells of the mammalian circadian clock," Nature Neuroscience, vol. 3, no. 12, pp. 1241-1247, 2000.

[105] S. Masri and P. Sassone-Corsi, "Plasticity and specificity of the circadian epigenome," Nature Neuroscience, vol. 13, no. 11, pp. 1324-1329, 2010.

[106] C. Guilding and H. D. Piggins, "Challenging the omnipotence of the suprachiasmatic timekeeper: are circadian oscillators present throughout the mammalian brain?" European Journal of Neuroscience, vol. 25, no. 11, pp. 3195-3216, 2007.

[107] J. D. Alvarez, D. Chen, E. Storer, and A. Sehgal, "Non-cyclic and developmental stage-specific expression of circadian clock proteins during murine spermatogenesis," Biology of Reproduction, vol. 69, no. 1, pp. 81-91, 2003.

[108] D. Morse, N. Cermakian, S. Brancorsini, M. Parvinen, and P. Sassone-Corsi, "No circadian rhythms in testis: period1 expression is Clock independent and developmentally regulated in the mouse," Molecular Endocrinology, vol. 17, no. 1, pp. 141-151, 2003.

[109] E. L. Bittman, L. Doherty, L. Huang, and A. Paroskie, "Period gene expression in mouse endocrine tissues," American Journal of Physiology, vol. 285, no. 3, pp. R561-R569, 2003.

[110] J. D. Alvarez and A. Sehgal, "The thymus is similar to the testis in its pattern of circadian clock gene expression," Journal of Biological Rhythms, vol. 20, no. 2, pp. 111-121, 2005.

[111] H. Dolatshad, F. C. Davis, and M. H. Johnson, "Circadian clock genes in reproductive tissues and the developing conceptus," Reproduction, Fertility and Development, vol. 21, no. 1, pp. 1-9, 2009.

[112] T. Amano, A. Matsushita, Y. Hatanaka et al., "Expression and functional analyses of circadian genes in mouse oocytes and preimplantation embryos: Cryl is involved in the meiotic process independently of circadian clock regulation1," Biology of Reproduction, vol. 80, no. 3, pp. 473-483, 2009. 
[113] T. Hamatani, M. G. Carter, A. A. Sharov, and M. S. H. Ko, "Dynamics of global gene expression changes during mouse preimplantation development," Developmental Cell, vol. 6, no. 1, pp. 117-131, 2004.

[114] K. Yagita, K. Horie, S. Koinuma et al., "Development of the circadian oscillator during differentiation of mouse embryonic stem cells in vitro," Proceedings of the National Academy of Sciences of the United States of America, vol. 107, no. 8, pp. 3846-3851, 2010.

[115] E. Kowalska, E. Moriggi, C. Bauer, C. Dibner, and S. A. Brown, "The circadian clock starts ticking at a developmentally early stage," Journal of Biological Rhythms, vol. 25, no. 6, pp. 442-449, 2010.

[116] H. Dolatshad, A. J. Cary, and F. C. Davis, "Differential expression of the circadian clock in maternal and embryonic tissues of mice," PloS One, vol. 5, no. 3, article e9855, 2010.

[117] M. Sládek, Z. Jindráková, Z. Bendová, and A. Sumová, "Postnatal ontogenesis of the circadian clock within the rat liver," American Journal of Physiology, vol. 292, no. 3, pp. R1224R1229, 2007.

[118] S. H. Yoo, S. Yamazaki, P. L. Lowrey et al., "PERIOD2::LUCIFERASE real-time reporting of circadian dynamics reveals persistent circadian oscillations in mouse peripheral tissues," Proceedings of the National Academy of Sciences of the United States of America, vol. 101, no. 15, pp. 5339-5346, 2004.

[119] H. Guo, J. M. Brewer, M. N. Lehman, and E. L. Bittman, "Suprachiasmatic regulation of circadian rhythms of gene expression in hamster peripheral organs: effects of transplanting the pacemaker," Journal of Neuroscience, vol. 26, no. 24, pp. 6406-6412, 2006.

[120] M. Stratmann and U. Schibler, "Properties, entrainment, and physiological functions of mammalian peripheral oscillators," Journal of Biological Rhythms, vol. 21, no. 6, pp. 494506, 2006.

[121] U. Schibler, “The 2008 Pittendrigh/Aschoff lecture: peripheral phase coordination in the mammalian circadian timing system," Journal of Biological Rhythms, vol. 24, no. 1, pp. 315, 2009.

[122] H. Terazono, T. Mutoh, S. Yamaguchi et al., "Adrenergic regulation of clock gene expression in mouse liver," Proceedings of the National Academy of Sciences of the United States of America, vol. 100, no. 11, pp. 6795-6800, 2003.

[123] C. Vollmers, S. Gill, L. DiTacchio, S. R. Pulivarthy, H. D. Le, and S. Panda, "Time of feeding and the intrinsic circadian clock drive rhythms in hepatic gene expression," Proceedings of the National Academy of Sciences of the United States of America, vol. 106, no. 50, pp. 21453-21458, 2009.

[124] F. Damiola, N. Le Minli, N. Preitner, B. Kornmann, F. Fleury-Olela, and U. Schibler, "Restricted feeding uncouples circadian oscillators in peripheral tissues from the central pacemaker in the suprachiasmatic nucleus," Genes and Development, vol. 14, no. 23, pp. 2950-2961, 2000.

[125] Y. Minami, T. Kasukawa, Y. Kakazu et al., "Measurement of internal body time by blood metabolomics," Proceedings of the National Academy of Sciences of the United States of America, vol. 106, no. 24, pp. 9890-9895, 2009.

[126] E. D. Buhr, S. H. Yoo, and J. S. Takahashi, "Temperature as a universal resetting cue for mammalian circadian oscillators," Science, vol. 330, no. 6002, pp. 379-385, 2010.

[127] N. Vujović, A. J. Davidson, and M. Menaker, "Sympathetic input modulates, but does not determine, phase of peripheral circadian oscillators," American Journal of Physiology, vol. 295, no. 1, pp. R355-R360, 2008.
[128] N. Le Minh, F. Damiola, F. Tronche, G. Schütz, and U. Schibler, "Glucocorticoid hormones inhibit food-induced phase-shifting of peripheral circadian oscillators," EMBO Journal, vol. 20, no. 24, pp. 7128-7136, 2002.

[129] H. J. Bohme, G. Sparmann, and E. Hofmann, "Biochemistry of liver development in the perinatal period," Experientia, vol. 39, no. 5, pp. 473-483, 1983.

[130] A. Meissner, T. S. Mikkelsen, H. Gu et al., "Genome-scale DNA methylation maps of pluripotent and differentiated cells," Nature, vol. 454, no. 7205, pp. 766-770, 2008.

[131] W. Reik, W. Dean, and J. Walter, "Epigenetic reprogramming in mammalian development," Science, vol. 293, no. 5532, pp. 1089-1093, 2001.

[132] H. Philippidis and F. J. Ballard, "The development of gluconeogenesis in rat liver: experiments in vivo," Biochemical Journal, vol. 113, no. 4, pp. 651-657, 1969.

[133] M. Suter, P. Bocock, L. Showalter et al., "Epigenomics: maternal high-fat diet exposure in utero disrupts peripheral circadian gene expression in nonhuman primates," FASEB Journal, vol. 25, no. 2, pp. 714-726, 2011.

[134] F. C. Davis and R. A. Gorski, "Development of hamster circadian rhythms: role of the maternal suprachiasmatic nucleus," Journal of Comparative Physiology, vol. 162, no. 5, pp. 601610, 1988.

[135] C. Jud and U. Albrecht, "Circadian rhythms in murine pups develop in absence of a functional maternal circadian clock," Journal of Biological Rhythms, vol. 21, no. 2, pp. 149-154, 2006.

[136] F. C. Davis and R. A. Gorski, "Development of hamster circadian rhythms: prenatal entrainment of the pacemaker," Journal of Biological Rhythms, vol. 1, no. 1, pp. 77-89, 1985.

[137] D. R. Weaver and S. M. Reppert, "Periodic feeding of SCNlesioned pregnant rats entrains the fetal biological clock," Developmental Brain Research, vol. 46, no. 2, pp. 291-296, 1989.

[138] N. Viswanathan, "Maternal entrainment in the circadian activity rhythm of laboratory mouse (C57BL/6J)," Physiology and Behavior, vol. 68, no. 1-2, pp. 157-162, 1999.

[139] H. Ohta, S. Honma, H. Abe, and K. I. Honma, "Periodic absence of nursing mothers phase-shifts circadian rhythms of clock genes in the suprachiasmatic nucleus of rat pups," European Journal of Neuroscience, vol. 17, no. 8, pp. 16281634, 2003.

[140] S. M. Reppert and W. J. Schwartz, "Maternal coordination of the fetal biological clock in utero," Science, vol. 220, no. 4600, pp. 969-971, 1983.

[141] N. Viswanathan, D. R. Weaver, S. M. Reppert, and F. C. Davis, "Entrainment of the fetal hamster circadian pacemaker by prenatal injections of the dopamine agonist SKF 38393," Journal of Neuroscience, vol. 14, no. 9, pp. 5393-5398, 1994.

[142] F. C. Davis and J. Mannion, "Entrainment of hamster pup circadian rhythms by prenatal melatonin injections to the mother," American Journal of Physiology, vol. 255, no. 3, pp. R439-R448, 1988.

[143] J. Grosse and F. C. Davis, "Transient entrainment of a circadian pacemaker during development by dopaminergic activation in Syrian hamsters," Brain Research Bulletin, vol. 48, no. 2, pp. 185-194, 1999.

[144] J. Grosse, A. Velickovic, and F. C. Davis, "Entrainment of Syrian hamster circadian activity rhythms by neonatal melatonin injections," American Journal of Physiology, vol. 270, no. 3, pp. R533-R540, 1996.

[145] M. Sládek, A. Sumová, Z. Kováčiková, Z. Bendová, K. Laurinová, and H. Illnerová, "Insight into molecular core clock 
mechanism of embryonic and early postnatal rat suprachiasmatic nucleus," Proceedings of the National Academy of Sciences of the United States of America, vol. 101, no. 16, pp. 6231-6236, 2004.

[146] X. Li and F. C. Davis, "Developmental expression of clock genes in the Syrian hamster," Developmental Brain Research, vol. 158, no. 1-2, pp. 31-40, 2005.

[147] L. Montoliu, J. A. Blendy, T. J. Cole, and G. Schutz, "Analysis of perinatal gene expression: hormone response elements mediate activation of a lacZ reporter gene in liver of transgenic mice," Proceedings of the National Academy of Sciences of the United States of America, vol. 92, no. 10, pp. 4244-4248, 1995.

[148] H. Sassi, R. Pictet, and T. Grange, "Glucocorticoids are insufficient for neonatal gene induction in the liver," Proceedings of the National Academy of Sciences of the United States of America, vol. 95, no. 10, pp. 5621-5625, 1998.

[149] H. Thomassin, M. Flavin, M. L. Espinás, and T. Grange, "Glucocorticoid-induced DNA demethylation and gene memory during development," EMBO Journal, vol. 20, no. 8, pp. 1974-1983, 2001.

[150] Y. Ji, Y. Qin, H. Shu, and X. Li, "Methylation analyses on promoters of mPer1, mPer2, and mCry1 during perinatal development," Biochemical and Biophysical Research Communications, vol. 391, no. 4, pp. 1742-1747, 2010.

[151] C. Dibner, D. Sage, M. Unser et al., "Circadian gene expression is resilient to large fluctuations in overall transcription rates," EMBO Journal, vol. 28, no. 2, pp. 123-134, 2009.

[152] Y. Fujimoto, K. Yagita, and H. Okamura, "Does mPER2 protein oscillate without its coding mRNA cycling?: posttranscriptional regulation by cell clock," Genes to Cells, vol. 11, no. 5, pp. 525-530, 2006.

[153] Y. Yamamoto, K. Yagita, and H. Okamura, "Role of cyclic mPer2 expression in the mammalian cellular clock," Molecular and Cellular Biology, vol. 25, no. 5, pp. 1912-1921, 2005.

[154] Y. Fan, A. Hida, D. A. Anderson, M. Izumo, and C. H. Johnson, "Cycling of CRYPTOCHROME proteins is not necessary for circadian-clock function in mammalian fibroblasts," Current Biology, vol. 17, no. 13, pp. 1091-1100, 2007.

[155] R. Numano, S. Yamazaki, N. Umeda et al., "Constitutive expression of the Period1 gene impairs behavioral and molecular circadian rhythms," Proceedings of the National Academy of Sciences of the United States of America, vol. 103, no. 10, pp. 3716-3721, 2006. 

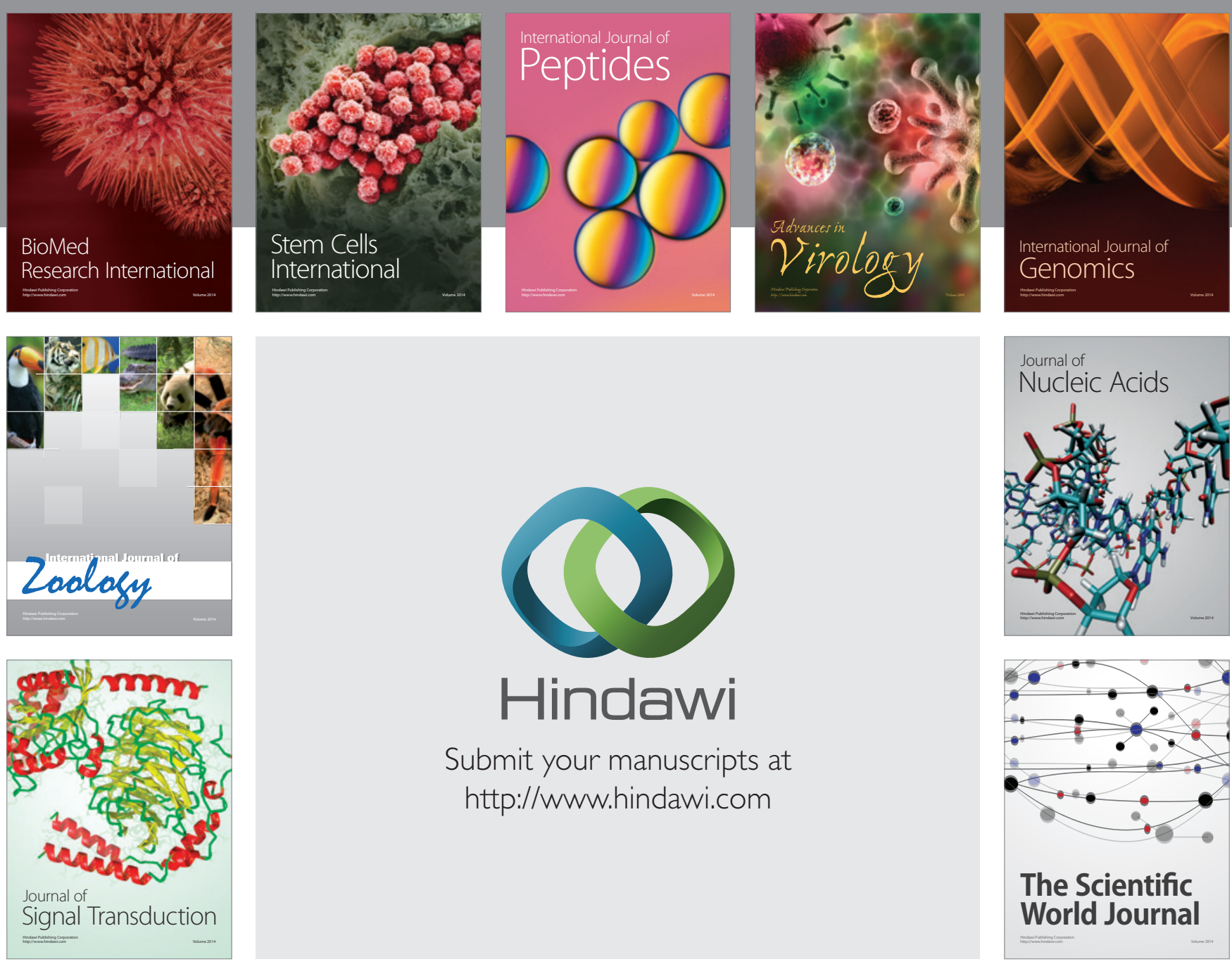

Submit your manuscripts at

http://www.hindawi.com
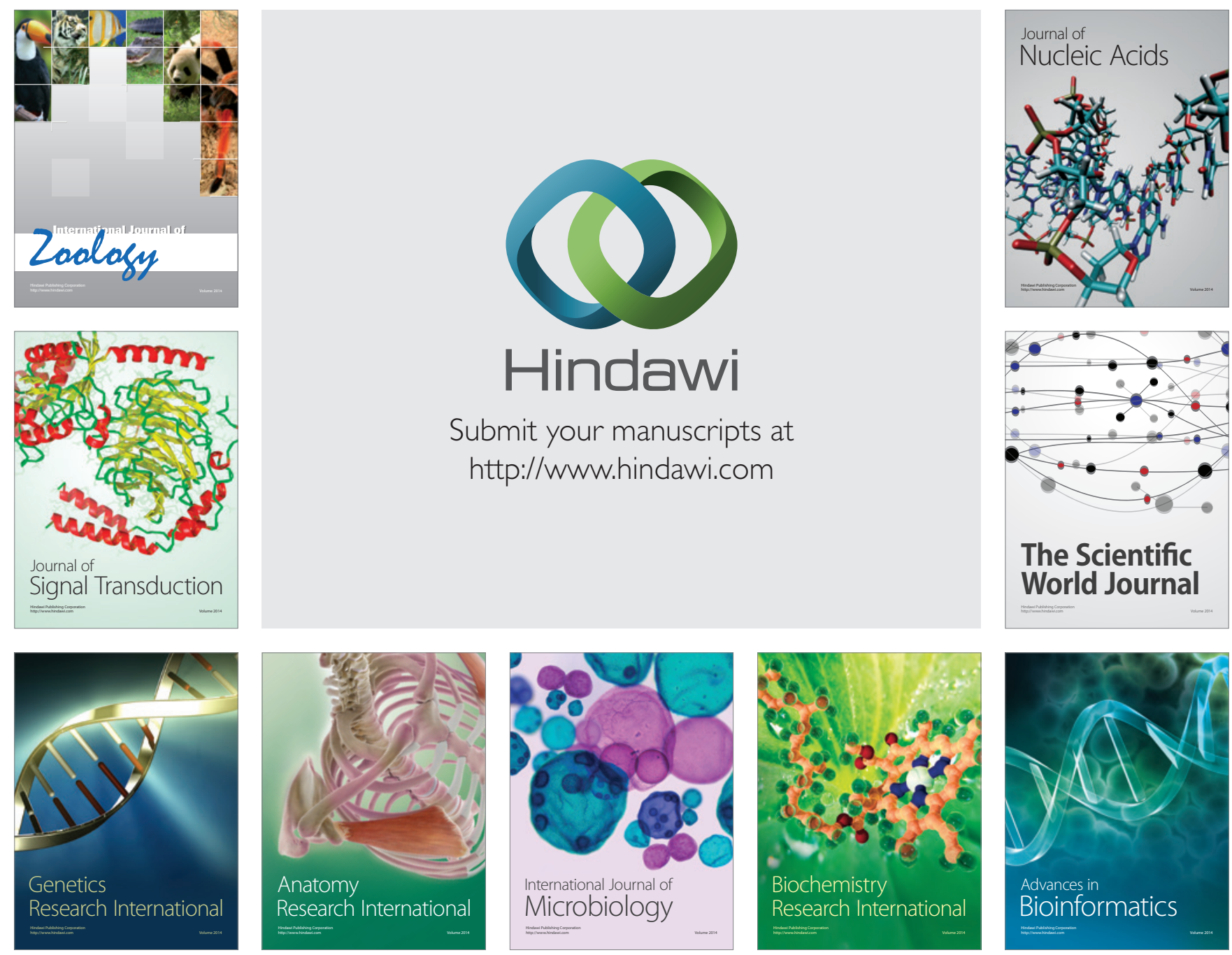

The Scientific World Journal
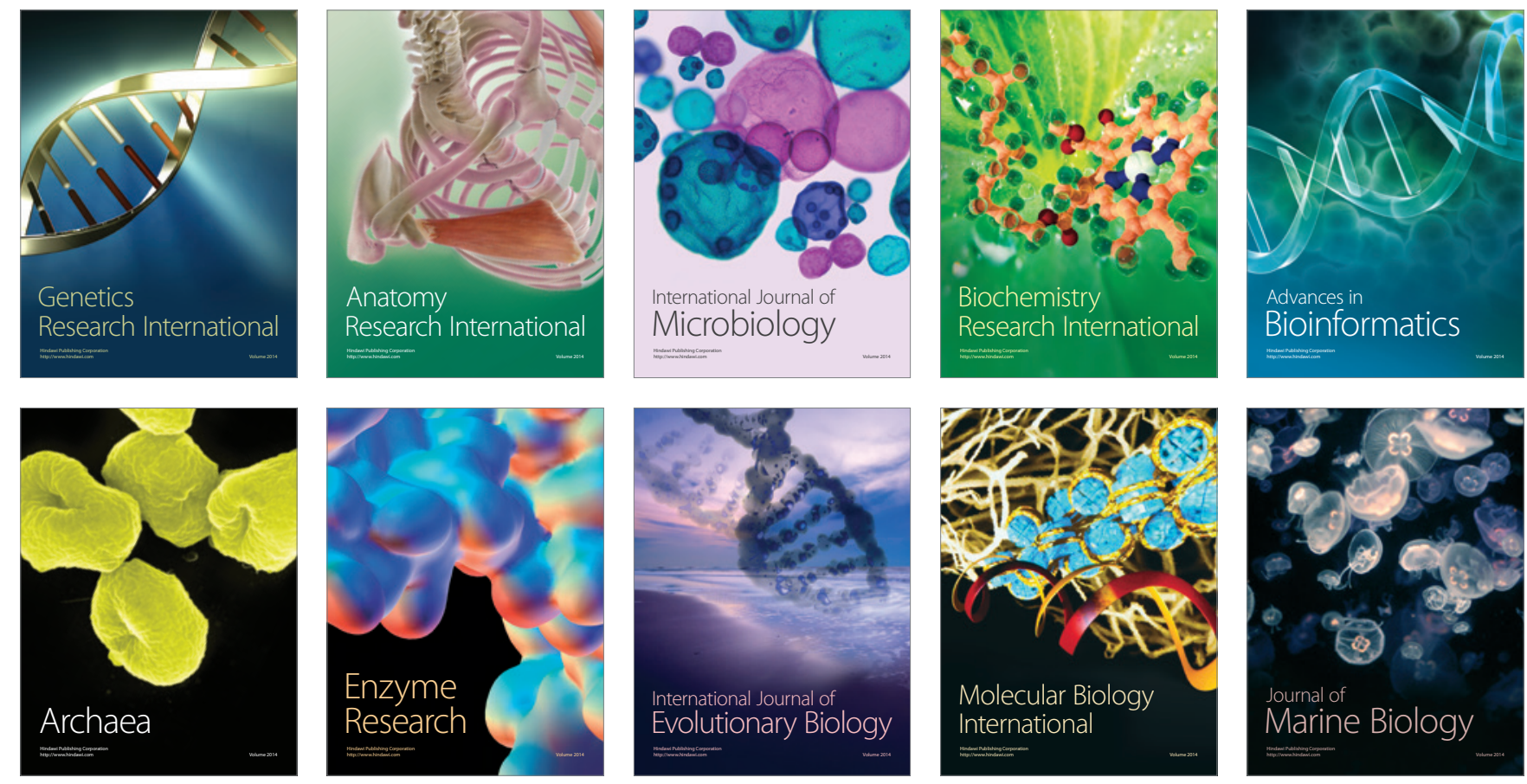